\title{
Mask Mandates and COVID-19 Related Symptoms in the US
}

\section{My Nguyen (1)}

Faculty of Economics and Public Management, Ho Chi Minh City Open University, Ho Chi Minh City, Vietnam
Correspondence: My Nguyen

Faculty of Economics and Public Management, Ho Chi Minh City Open University, 35-37 Ho Hao Hon, District I. Ho Chi Minh City, Vietnam

Tel +84-28-38364748

Fax +84-28-39207639

Email my.ngt@ou.edu.vn
Purpose: This study investigates the extent to which the Public Mask Mandate, a policy that requires the use of face masks in public, can protect people from developing COVID-19 symptoms during the initial stage of the pandemic from mid-April to early June 2020 in the United States (US).

Methods: We employ the difference-in-differences model that exploits the differential timing of the mask mandate implementation across states.

Results: Our findings show that the Public Mask Mandate significantly lowers the incidence of developing all COVID-19 symptoms by 0.29 percentage points. The estimate implies an average reduction of $290 \%$, compared to the proportion of the mandate-unaffected individuals who display all symptoms $(0.1 \%)$.

Conclusion: The study provides suggestive evidence for the health benefits of wearing masks in public in the initial stage of the COVID-19 pandemic. The study also highlights the relevance of public mask wearing for the ongoing pandemic where the vaccination rate is precarious and access to vaccines is still limited in many countries.

Keywords: COVID-19, coronavirus symptoms, mask mandates, face masks

\section{Introduction}

As the most dreadful public health threat related to a respiratory virus since the 1918 H1N1 influenza pandemic, COVID-19 has caused hundreds of thousands of deaths and infected millions of people across the globe. The consequences of the COVID-19 pandemic also include deteriorating economic performance, rising inequality, and acute psychological distress. ${ }^{1-4}$ During the initial stage of the pandemic, governments across countries relied on non-pharmaceutical interventions as the key strategy in curtailing the transmission of the virus. One example is the policy regarding social distancing such as public gathering bans. Another policy response that was met with substantial opposition at the onset of the COVID-19 breakout is the Public Mask Mandate that requires the use of face masks in public.

This paper evaluates whether the Public Mask Mandate can protect people from developing symptoms of COVID-19 at the beginning of the pandemic. We cover all 11 symptoms established by the Disease Control and Prevention (CDC), including fever or chills, cough, shortness of breath, fatigue, muscle or body aches, headache, loss of taste or smell, sore throat, congestion or runny nose, nausea or vomiting, and diarrhea. The contribution of our study is two folds. First, by examining the effectiveness of wearing face masks in public, our study can provide meaningful implications for the ongoing pandemic where there are still a large number of 
people unvaccinated and access to vaccines is still limited in many countries. The result of our study can also be relevant for future respiratory pandemics. Second, although the correlation between face masks and COVID-19 infection is documented in several previous studies, very few attempts have been made to ensure internal validity and establish a causal relationship. We address this issue by exploiting the differential timing of the mask mandate implementation across states in the US within a difference-in-differences framework.

The role of subnational governments in the US during the pandemic motivates our empirical methodology. Whereas centralized strategies were enforced to contain COVID-19 transmission in many countries like China and Vietnam, in the US, state governments were responsible for devising and implementing pandemic control policies. Specifically in this context, different states at different times implemented the Public Mask Mandate that requires the use of mask or face-covering in public places. The sharp and staggering changes across states in maskwearing requirements allow for the adoption of the difference-in-differences model. In other words, the differencein-differences model exploits the differential timing of the mask mandate implementation across the US.

Our work can be related to two strands of literature. The first line of literature focuses on the importance of non-pharmaceutical interventions in combating COVID19. For example, measures such as mass quarantine, social distancing, and face masking can help decrease contact rate, the number of positive cases, and the number of deaths. ${ }^{5-8}$ Our study also fits into the second line of work which provides epidemiological evidence on the efficacy of face masks in preventing the transmission of respiratory virus. In particular, surgical masks are found to decrease the release of influenza virus and coronavirus particles in respiratory droplets into the environment. ${ }^{9}$ Homemade cloth masks, despite being less competent than surgical masks, are still much more capable of blocking the dispersal of microorganism-bearing droplets than the without-mask scenario. ${ }^{10}$

The study makes use of the COVID Impact Survey that focuses exclusively on individual experiences during the COVID-19 outbreak in the US. Within a difference-indifferences framework, we find that the Public Mask Mandate lowers the incidence of developing all COVID19 symptoms by 0.29 percentage points. Taking the proportion of individuals who are not subject to the mandate and display all symptoms (around $0.1 \%$ ) as the benchmark, the estimate implies the average decrease by $290 \%$.

The result provides evidence for the enormous health benefits of wearing masks in public in the initial stage of the COVID-19 pandemic. Even with the availability of vaccines, mask use is still relevant for the ongoing pandemic since there is still a probability of the fully vaccinated getting infected with the virus. ${ }^{11}$ Besides, the vaccination rate can be precarious, which means that loosening pandemic-related restrictions such as masking or face-covering in public places should be conducted very carefully. In many developing countries where access to vaccines is still limited, mask use should still be one of the effective nonpharmaceutical measures to downsize community transmission and lessen the burden of the pandemic. The mask use policy might be implemented in conjunction with other strategies such as social distancing to maximize potential benefits, especially in situations where the vaccination rate is low. Public mask-wearing is highly effective at reducing the spread of the virus when compliance is high. ${ }^{12}$ Therefore, governments need to communicate with the public on the benefits of face masks to ensure the highest compliance. It is also important for political leaders and doctors to serve as role models for the public. ${ }^{13}$ Some degree of interventions in the mask market such as a subsidy are justified given the positive externalities it can generate. When there is a shortage of face masks, the use of homemade masks should be encouraged since the efficacy of homemade masks, despite being lower than medical masks, is superior to no protection at all. ${ }^{10}$

\section{Materials and Methods \\ Data}

\section{Health and Demographics}

The first source of data is the COVID Impact Survey (CIS), which is funded by the Data Foundation and conducted by the National Opinion Research Center at the University of Chicago (NORC). The dataset provides detailed information on American experiences during the COVID-19 pandemic. Respondents are rewarded a small amount of money as an incentive to complete the survey. Each survey wave occurs over a week-long period. We utilize three survey waves that were conducted during the initial stage of the pandemic, including Wave 1: April 20 April 26, 2020, Wave 2: May 04 - May 10, 2020, and Wave 3: May 30 - June 08, 2020. The survey sample 
targets a nationally representative sample of adults age 18 and older in the US. The sample is selected using sampling strata based on age, gender, race/ethnicity, and education (48 sampling strata in total). The size of the selected sample per sampling stratum is determined by the population distribution for each stratum. Sample selection further takes into account expected differential interview completion rates by demographic groups. Therefore, the set of members completing the interview is also a representative sample of the target population. To reassure the representativeness, Table A1 in the Appendix compares some key demographic characteristics between the CIS and the Census Population Survey. The differences between the CIS sample and the national statistics are all small and acceptable (around \pm 0.1 percentage point), thus confirming the representativeness of the CIS sample.

Standard demographic characteristics, such as gender, educational attainment, race, age group, urban/rural status, household size, and share of children in the household, are obtained straight from the CIS. Most importantly, the CIS enables us to construct measures indicating whether individuals have COVID-19 symptoms. In particular, respondents were asked about whether they experienced any of the listed symptoms in the past 7 days, such as fever, chills, runny or stuffy nose, chest congestion, cough, sore throat, muscle or body aches, headaches, fatigue, or tiredness, shortness of breath, etc. The answers can be Yes, No, or Not Sure. We drop the Not Sure answers and focus on the other two. This comprehensive set of symptoms covers all 11 COVID-19 related symptoms announced by the Disease Control and Prevention (CDC). Readers can go to https://www.cdc.gov/coronavirus/2019-ncov/symptomstesting/symptoms.html for more information regarding the symptoms indicating that people may have COVID-19. Besides, these symptoms have been well established to be strong predictors of COVID-19 infection. For systematic reviews and meta-analyses on prior studies of the relationship between these symptoms and COVID-19 infection, please see the works of Alimohamadi et al, Grant et al, and Assaker et al. ${ }^{14-16}$

Following the CDC guidance, we construct 11 onezero variables indicating symptoms people may have after exposure to the virus. In particular, the variables include: (i) Fever/Chills equals one if having fever or chills, (ii) Cough equals one if having cough, (iii) Shortness of Breath equals one if having shortness of breath or difficulty breathing, (iv) Fatigue equals one if having fatigue, (v) Muscle/Body Aches equals one if having muscle or body aches, (vi) Headache equals one if having headaches, (vii) Loss of Appetite equals one if having loss of taste or smell, (viii) Sore Throat equals one if having a sore throat, (ix) Congestion/Runny Nose equals one if having congestion or runny nose, (x) Nausea/ Vomiting equals one if having nausea or vomiting, and (xi) Diarrhea equals one if having diarrhea. While being well documented in prior studies, it is still interesting to examine the relationship between these symptoms and COVID-19 infection with the newly constructed data. To do so, we regress each of the symptoms on the state-level Positive Rate, which is simply the number of positive tests divided by the total number of tests for the survey week. The positivity rate not only measures the outbreak's severity but also accounts for the limitations of testing. It is worth noting that since the CDC is not publishing COVID19 tests for each state on a daily basis, we rely on the COVID Tracking Project for the statistics. Johns Hopkins also relies on this data for its COVID-19 Testing Insights Initiative in supporting the public and policymakers to understand and make decisions about pandemic-related matters. The quantified relationships between each of the 11 symptoms and COVID-19 infection, proxied by Positive Rate, are reported in Tables A2 and $\underline{\mathrm{A} 3}$ in the Appendix. It is not surprising that the relationships of interest are all positive and statistically significant, thus lending some supports to prior studies.

We also construct two groups of measures reflecting the overall situation. The first group focuses on the nominal number of symptoms (out of 11 ones announced by the $\mathrm{CDC}$ ) that the respondent experienced, namely: (i) Number of Symptoms stands for the number of symptoms, and (ii) Log Number of Symptoms is calculated as the log of one plus the number of symptoms. The second group includes one-zero variables, namely: (i) Any Symptoms takes the value of one if the respondent reports having one or more symptoms and zero otherwise, (ii) Six or More Symptoms takes the value of one if the respondent reports exhibiting six or more symptoms, and (iii) All Symptoms takes the value of one if the respondent reports displaying all 11 symptoms of COVID-19.

\section{Public Mask Mandate}

Our main explanatory variable is an indicator of whether wearing face masks in public is required in the respondent's residing state at the period of the survey. The implementation dates of mask mandates in public are collected from the state government websites. Given 
these implementation dates and the timing of the survey, we can construct our main explanatory indicating whether respondents are required to wear face masks in public. In particular, the main explanatory, denoted by PMM (ie Public Mask Mandate), takes a value of one if an individual is interviewed after the law being imposed and before the law being lifted, and zero otherwise. Table 1 presents the mandate names and the timing of implementation across states as of June 08, 2020. Panels

Table I Public Mask Mandate by State as of June 08, 2020

\begin{tabular}{|c|c|c|c|}
\hline State Name & $\begin{array}{l}\text { Date } \\
\text { Enacted }\end{array}$ & $\begin{array}{l}\text { Date } \\
\text { Ended }\end{array}$ & Policy Name \\
\hline Connecticut & $\begin{array}{l}\text { Apr 17, } \\
2020\end{array}$ & $\begin{array}{l}\text { Still in } \\
\text { Effect }\end{array}$ & Executive Order No. 7BB \\
\hline Delaware & $\begin{array}{l}\text { May 0I, } \\
2020\end{array}$ & $\begin{array}{l}\text { Still in } \\
\text { Effect }\end{array}$ & $\begin{array}{l}\text { Thirteenth Modification to } \\
\text { State of Emergency }\end{array}$ \\
\hline Hawaii & $\begin{array}{l}\text { Apr 20, } \\
2020\end{array}$ & $\begin{array}{l}\text { Still in } \\
\text { Effect }\end{array}$ & $\begin{array}{l}\text { Emergency Order No. 2020- } \\
07\end{array}$ \\
\hline Illinois & $\begin{array}{l}\text { May 0I, } \\
2020\end{array}$ & $\begin{array}{l}\text { Still in } \\
\text { Effect }\end{array}$ & Executive Order 2020-32 \\
\hline Maine & $\begin{array}{l}\text { May 0I, } \\
2020\end{array}$ & $\begin{array}{l}\text { Still in } \\
\text { Effect }\end{array}$ & $\begin{array}{l}\text { Executive Order } 49 \mathrm{FY} 19 / \\
20\end{array}$ \\
\hline Marryland & $\begin{array}{l}\text { Apr 18, } \\
2020\end{array}$ & $\begin{array}{l}\text { Still in } \\
\text { Effect }\end{array}$ & $\begin{array}{l}\text { Governor Order No. 20-04- } \\
|5-0|\end{array}$ \\
\hline Massachusetts & $\begin{array}{l}\text { May 06, } \\
2020\end{array}$ & $\begin{array}{l}\text { Still in } \\
\text { Effect }\end{array}$ & COVID-19 Order No. 3I \\
\hline Michigan & $\begin{array}{l}\text { Apr 26, } \\
2020\end{array}$ & $\begin{array}{l}\text { Still in } \\
\text { Effect }\end{array}$ & $\begin{array}{l}\text { Executive Order No. 2020- } \\
60\end{array}$ \\
\hline New Jersey & $\begin{array}{l}\text { Apr 10, } \\
2020\end{array}$ & $\begin{array}{l}\text { Still in } \\
\text { Effect }\end{array}$ & Executive Order No. 125 \\
\hline New Mexico & $\begin{array}{l}\text { May I5, } \\
2020\end{array}$ & $\begin{array}{l}\text { Still in } \\
\text { Effect }\end{array}$ & $\begin{array}{l}\text { Public Health Emergency } \\
\text { Orders of May I5, } 2020\end{array}$ \\
\hline New York & $\begin{array}{l}\text { Apr 15, } \\
2020\end{array}$ & $\begin{array}{l}\text { Still in } \\
\text { Effect }\end{array}$ & Executive Order No. 202.17 \\
\hline Pennsylvania & $\begin{array}{l}\text { Apr 17, } \\
2020\end{array}$ & $\begin{array}{l}\text { Still in } \\
\text { Effect }\end{array}$ & $\begin{array}{l}\text { Order of the Secretary of } \\
\text { the Department of Health }\end{array}$ \\
\hline Rhode Island & $\begin{array}{l}\text { Apr 20, } \\
2020\end{array}$ & $\begin{array}{l}\text { Still in } \\
\text { Effect }\end{array}$ & Executive Order $20-30$ \\
\hline Virginia & $\begin{array}{l}\text { May 29, } \\
2020\end{array}$ & $\begin{array}{l}\text { Still in } \\
\text { Effect }\end{array}$ & Executive Order 63 \\
\hline $\begin{array}{l}\text { Washington } \\
\text { D.C. }\end{array}$ & $\begin{array}{l}\text { Apr 17, } \\
2020\end{array}$ & $\begin{array}{l}\text { Still in } \\
\text { Effect }\end{array}$ & Mayor's Order 2020-067 \\
\hline
\end{tabular}

Notes: States that are not present in this table did not implement the Public Mask Mandate during the time of our study.
A and B of Table A4 in the Appendix detail summary statistics for independent and outcome variables by the status of exposure to the mandate.

\section{Method}

To examine how the Public Mask Mandate can protect individuals from developing the symptoms of COVID19, we exploit the staggered implementation of the mask mandates across the US during the initial stage of the pandemic in the following difference-in-differences (DID) framework,

$$
\mathrm{Y}_{\text {ist }}=\beta_{0}+\beta_{1} \mathrm{PMM}_{\text {ist }}+\delta_{\mathrm{s}}+\theta_{\mathrm{t}}+\mathrm{X}_{\text {ist }} \Omega+\epsilon_{\text {ist }}
$$

where the subscripts $\mathrm{i}, \mathrm{s}$, and $\mathrm{t}$ refer to the individual, state, and time (week) of the survey. The dependent variable $Y_{\text {ist }}$ stands for various measures of COVID-19 symptoms the individual reports to have within the last seven days, including (i) the Number of Symptoms, (ii) the Log Number of Symptoms, (iii) an indicator for whether the individual has at least one symptom (Any Symptoms), (iv) an indicator for whether the individual has at least six symptoms (Six or More Symptoms), and (v) an indicator for whether the individual has all 11 symptoms (All Symptoms). Besides these five main variables, we further examine whether the individual displays each of the 11 symptoms (Fever/Chill, Cough, Shortness of Breath, Fatigue, Muscle/Body Aches, Headache, Loss of Appetite, Sore Throat, Congestion/Runny Nose, Nausea/ Vomiting, Diarrhea) individually.

Our main independent variable, $\mathrm{PMM}_{\text {ist }}$, is a dummy variable that takes the value of one if the Public Mask Mandate is effective in the individual's residence state at the survey week. We denote by $\delta_{\mathrm{s}}$ and $\theta_{\mathrm{t}}$ state and week fixed effects, respectively. The vector $\mathrm{X}^{\prime}$ ist is the covariate that captures individual characteristics including gender, educational attainment, race, age group, urban/rural status, household size, and share of children in the household. Finally, $\epsilon_{\text {ist }}$ stands for the error term. Standard errors throughout the paper are clustered at the statistical area by week level where the statistical area in the survey is either a state or a metropolitan statistical area. Sampling weights are used in all of the regressions since the unweighted estimates may be biased in the presence of endogenous sampling.

The coefficient of interest $\beta_{1}$ summarizes the extent to which the Public Mask Mandate affects individuals' development of COVID-19 symptoms. In this DID framework, the treatment group consists of individuals subject to the Public Mask Mandate at the survey time. Individuals who are not 
exposed to the mandate in the survey week constitute the control group. Our identification hinges upon the differential timing of the Public Mask Mandate across states. In other words, we compare the health outcomes for individuals under the Public Mask Mandate at the time of survey with those who reside in the same state but were surveyed when the mandate had not been enforced, relative to the analogous differences for individuals living in states where Public Mask Mandate was put into effect in a different time frame or never invoked such a mandate. The data underlying this study, the COVID Impact Survey (CIS), is freely available at https://www.covid-impact.org/.
Results

\section{The Impacts of Public Mask Mandate on} Overall COVID-19 Symptoms

The estimated impacts of the Public Mask Mandate on the overall COVID-19 symptoms are reported in Table 2. Each column is a separate regression and the column heading indicates the outcome variable. All regressions control for state and week fixed effects as well as a full set of individual characteristics. Overall, Table 2 suggests that the implementation of the Public Mask Mandate is effective in suppressing the development of COVID-19 symptoms.

Table 2 The Impact of Public Mask Mandate: Overall Symptoms

\begin{tabular}{|c|c|c|c|c|c|}
\hline & $\begin{array}{l}\text { Number of } \\
\text { Symptoms } \\
\text { (I) }\end{array}$ & $\begin{array}{l}\text { Log Number of } \\
\text { Symptoms } \\
\text { (2) }\end{array}$ & $\begin{array}{c}\text { Any } \\
\text { Symptoms } \\
\text { (3) }\end{array}$ & $\begin{array}{l}\text { Six or More } \\
\text { Symptoms } \\
\text { (4) }\end{array}$ & $\begin{array}{c}\text { All } \\
\text { Symptoms } \\
(5)\end{array}$ \\
\hline Public Mask Mandate & $\begin{array}{c}-0.4342 * * * \\
(0.0962)\end{array}$ & $\begin{array}{c}-0.1624 * * * \\
(0.0313)\end{array}$ & $\begin{array}{c}-0.1052^{* * *} \\
(0.0124)\end{array}$ & $\begin{array}{c}-0.047 I^{* * *} \\
(0.0050)\end{array}$ & $\begin{array}{c}-0.0029 * * * \\
(0.0002)\end{array}$ \\
\hline Being Male & $\begin{array}{c}-0.1628 * * \\
(0.0644)\end{array}$ & $\begin{array}{c}-0.0576 * * \\
(0.0254)\end{array}$ & $\begin{array}{l}-0.0260 \\
(0.0208)\end{array}$ & $\begin{array}{l}-0.0033 \\
(0.0059)\end{array}$ & $\begin{array}{l}-0.0001 \\
(0.0005)\end{array}$ \\
\hline Having Bachelor's Degree & $\begin{array}{c}-0.1344 * * \\
(0.057 I)\end{array}$ & $\begin{array}{l}-0.0243 \\
(0.0228)\end{array}$ & $\begin{array}{c}0.0102 \\
(0.0167)\end{array}$ & $\begin{array}{c}-0.0239 * * * \\
(0.0055)\end{array}$ & $\begin{array}{l}-0.0007 \\
(0.0005)\end{array}$ \\
\hline Being Non-white & $\begin{array}{c}0.1070 \\
(0.0959)\end{array}$ & $\begin{array}{c}0.0391 \\
(0.0374)\end{array}$ & $\begin{array}{c}0.0261 \\
(0.0294)\end{array}$ & $\begin{array}{c}0.0040 \\
(0.0104)\end{array}$ & $\begin{array}{l}-0.0016 \\
(0.0018)\end{array}$ \\
\hline Living in Urban Areas & $\begin{array}{l}-0.0142 \\
(0.0758)\end{array}$ & $\begin{array}{l}-0.0072 \\
(0.027 I)\end{array}$ & $\begin{array}{l}-0.0006 \\
(0.0173)\end{array}$ & $\begin{array}{c}0.0058 \\
(0.0061)\end{array}$ & $\begin{array}{l}0.0006 * * \\
(0.0002)\end{array}$ \\
\hline Household Size & $\begin{array}{l}0.0599 * \\
(0.0354)\end{array}$ & $\begin{array}{l}0.0176 * * \\
(0.0076)\end{array}$ & $\begin{array}{l}0.0123^{* *} \\
(0.0053)\end{array}$ & $\begin{array}{c}0.0037 \\
(0.0046)\end{array}$ & $\begin{array}{l}-0.0000 \\
(0.0001)\end{array}$ \\
\hline Share of Children $(<18)$ & $\begin{array}{l}-0.3956 \\
(0.2721)\end{array}$ & $\begin{array}{c}-0.1623 * * \\
(0.0822)\end{array}$ & $\begin{array}{c}-0.1429 * * \\
(0.0583)\end{array}$ & $\begin{array}{c}0.0079 \\
(0.0337)\end{array}$ & $\begin{array}{c}-0.0017^{* *} \\
(0.0009)\end{array}$ \\
\hline Age 18-29 & $\begin{array}{c}0.4566^{* * *} \\
(0.1035)\end{array}$ & $\begin{array}{c}0.1763 * * * \\
(0.0340)\end{array}$ & $\begin{array}{c}0.1045 * * * \\
(0.0195)\end{array}$ & $\begin{array}{l}0.0283 * * \\
(0.0125)\end{array}$ & $\begin{array}{l}-0.0001 \\
(0.0004)\end{array}$ \\
\hline Age $30-34$ & $\begin{array}{c}0.3827 * * * \\
(0.0548)\end{array}$ & $\begin{array}{c}0.1203 * * * \\
(0.0211)\end{array}$ & $\begin{array}{c}0.0477^{* * *} \\
(0.0180)\end{array}$ & $\begin{array}{c}0.0308 * * * \\
(0.0058)\end{array}$ & $\begin{array}{c}0.0007 \\
(0.0009)\end{array}$ \\
\hline Age 45-59 & $\begin{array}{c}0.1159 \\
(0.0737)\end{array}$ & $\begin{array}{c}0.0425 \\
(0.0275)\end{array}$ & $\begin{array}{c}0.0240 \\
(0.0178)\end{array}$ & $\begin{array}{c}0.0054 \\
(0.0058)\end{array}$ & $\begin{array}{c}0.0004 \\
(0.0005)\end{array}$ \\
\hline \multicolumn{6}{|l|}{ Age 60+ (Omitted) } \\
\hline $\begin{array}{l}\text { State \& Week FE } \\
\text { Observations }\end{array}$ & $\begin{array}{c}\checkmark \\
16,580\end{array}$ & $\begin{array}{c}\checkmark \\
16,580\end{array}$ & $\begin{array}{c}\checkmark \\
16,580\end{array}$ & $\begin{array}{c}\checkmark \\
16,580\end{array}$ & $\begin{array}{c}\checkmark \\
16,580\end{array}$ \\
\hline
\end{tabular}

Notes: ${ }^{*} \mathrm{p}<0.1,{ }^{*} \mathrm{p}<0.05,{ }^{*} * *_{\mathrm{p}}<0.01$. Robust standard errors are clustered at the Statistical Area-by-Week level. Sampling weights are used since the unweighted estimates may be biased in the presence of endogenous sampling.

Abbreviation: FE, fixed effects. 
Evident from Column 1, the number of COVID-19 symptoms declines by 0.43 for those residing in states where people are required to wear masks in public. Column 2 indicates that using the log number of symptoms as the dependent variable does not change the conclusion. Next, as shown in Columns 3 and 4, individuals exposed to the mandate are 10.52 and 4.71 percentage points less likely to exhibit any symptoms and at least six symptoms within the last seven days, respectively. Finally, according to Column 5, the Public Mask Mandate further lowers the incidence of developing all 11 symptoms by 0.29 percentage points. Taking the proportion of mandate unaffected individuals who display all symptoms $(0.1 \%$, Panel B of Table A4) as the benchmark, the estimate implies the average decrease in developing all 11 symptoms by $290 \%$.

\section{The Impacts of Public Mask Mandate by Symptoms}

While the estimates presented in Table 2 are all statistically and economically significant, it could be the case that such significant levels are driven by just one or two symptoms. Therefore, we proceed to examine the impacts of the Public Mask Mandate for each symptom individually. The estimating results from this exercise are reported in Tables 3 and 4.

We find strong statistical evidence supporting the effectiveness of the Public Mask Mandate in suppressing almost all symptoms of COVID-19. Nine out of 11 coefficients are statistically significant. According to Columns 1 to 3 of Table 3, individuals residing in states where the Public Mask Mandate is in place are 4.83,1.96, and 3.10 percentage points less likely to suffer from fever/chills, cough, and shortness of breath, respectively. These estimates correspond to the

Table 3 The Impact of Public Mask Mandate by Symptom

\begin{tabular}{|c|c|c|c|c|c|c|}
\hline & $\begin{array}{l}\text { Fever or Chills } \\
\text { (I) }\end{array}$ & $\begin{array}{l}\text { Cough } \\
\text { (2) }\end{array}$ & $\begin{array}{l}\text { Shortness of Breath } \\
\text { (3) }\end{array}$ & $\begin{array}{c}\text { Fatigue } \\
\text { (4) }\end{array}$ & $\begin{array}{c}\text { Muscle or Body Aches } \\
\text { (5) }\end{array}$ & $\begin{array}{c}\text { Headache } \\
\text { (6) }\end{array}$ \\
\hline Public Mask Mandate & $\begin{array}{c}-0.0483 * * * * \\
(0.0116)\end{array}$ & $\begin{array}{c}-0.0196 * * \\
(0.0095)\end{array}$ & $\begin{array}{l}-0.0310 * \\
(0.0163)\end{array}$ & $\begin{array}{c}-0.0770 * * * \\
(0.0060)\end{array}$ & $\begin{array}{c}-0.07 \mid 2^{* * *} \\
(0.0245)\end{array}$ & $\begin{array}{c}-0.0430 * * * \\
(0.0121)\end{array}$ \\
\hline Being M2ale & $\begin{array}{l}-0.0236 \\
(0.0173)\end{array}$ & $\begin{array}{l}-0.0009 \\
(0.0139)\end{array}$ & $\begin{array}{l}-0.0100 \\
(0.0090)\end{array}$ & $\begin{array}{l}-0.0103 \\
(0.0114)\end{array}$ & $\begin{array}{c}0.0003 \\
(0.0086)\end{array}$ & $\begin{array}{l}-0.0149 \\
(0.0106)\end{array}$ \\
\hline Having Bachelor's Degree & $\begin{array}{l}-0.0100 \\
(0.0140)\end{array}$ & $\begin{array}{l}-0.0039 \\
(0.0092)\end{array}$ & $\begin{array}{c}-0.028 I^{* * * *} \\
(0.009 I)\end{array}$ & $\begin{array}{l}-0.0073 \\
(0.0064)\end{array}$ & $\begin{array}{c}-0.0225^{* *} \\
(0.0089)\end{array}$ & $\begin{array}{c}-0.0143^{*} \\
(0.0077)\end{array}$ \\
\hline Being Non-white & $\begin{array}{l}-0.0062 \\
(0.0288)\end{array}$ & $\begin{array}{c}0.0271 \\
(0.0223)\end{array}$ & $\begin{array}{c}0.0692^{* * *} \\
(0.0163)\end{array}$ & $\begin{array}{l}-0.0209 \\
(0.0135)\end{array}$ & $\begin{array}{c}0.0151 \\
(0.0113)\end{array}$ & $\begin{array}{c}0.0283 \\
(0.0207)\end{array}$ \\
\hline Living in Urban Areas & $\begin{array}{l}-0.0071 \\
(0.0194)\end{array}$ & $\begin{array}{l}-0.0189 \\
(0.0173)\end{array}$ & $\begin{array}{c}0.0012 \\
(0.0083)\end{array}$ & $\begin{array}{c}0.0095 \\
(0.0117)\end{array}$ & $\begin{array}{l}-0.0013 \\
(0.0122)\end{array}$ & $\begin{array}{c}0.0056 \\
(0.0169)\end{array}$ \\
\hline Household Size & $\begin{array}{c}0.0050 \\
(0.0051)\end{array}$ & $\begin{array}{l}0.0107 * * \\
(0.0046)\end{array}$ & $\begin{array}{c}0.0127^{* * * *} \\
(0.0046)\end{array}$ & $\begin{array}{c}0.0007 \\
(0.0034)\end{array}$ & $\begin{array}{c}0.0027 \\
(0.0040)\end{array}$ & $\begin{array}{l}0.0094 * * \\
(0.004 I)\end{array}$ \\
\hline Share of Children $(<18)$ & $\begin{array}{l}-0.0600 \\
(0.0464)\end{array}$ & $\begin{array}{c}-0.0680 * * \\
(0.0294)\end{array}$ & $\begin{array}{l}-0.0569 \\
(0.0364)\end{array}$ & $\begin{array}{l}-0.0360 \\
(0.0305)\end{array}$ & $\begin{array}{l}-0.0130 \\
(0.0353)\end{array}$ & $\begin{array}{c}-0.0642^{*} \\
(0.037 I)\end{array}$ \\
\hline Age 18-29 & $\begin{array}{c}0.0697 * * * \\
(0.0177)\end{array}$ & $\begin{array}{c}0.0292^{* * *} \\
(0.0106)\end{array}$ & $\begin{array}{c}0.0143 \\
(0.0144)\end{array}$ & $\begin{array}{c}0.0420 * * * \\
(0.0133)\end{array}$ & $\begin{array}{c}0.0564 * * * \\
(0.0181)\end{array}$ & $\begin{array}{c}0.0525 * * * \\
(0.0166)\end{array}$ \\
\hline Age $30-34$ & $\begin{array}{l}0.0411 * * \\
(0.0161)\end{array}$ & $\begin{array}{l}0.0347 * * \\
(0.0147)\end{array}$ & $\begin{array}{c}0.0283 * * * \\
(0.0092)\end{array}$ & $\begin{array}{c}0.0267 * * * \\
(0.0068)\end{array}$ & $\begin{array}{c}0.0382 * * * \\
(0.0109)\end{array}$ & $\begin{array}{c}0.0358 * * * \\
(0.0121)\end{array}$ \\
\hline Age 45-59 & $\begin{array}{c}0.0077 \\
(0.0092)\end{array}$ & $\begin{array}{c}0.0002 \\
(0.0097)\end{array}$ & $\begin{array}{c}0.0046 \\
(0.0088)\end{array}$ & $\begin{array}{c}0.0075 \\
(0.0120)\end{array}$ & $\begin{array}{l}0.0182 * * \\
(0.0084)\end{array}$ & $\begin{array}{c}0.0032 \\
(0.0132)\end{array}$ \\
\hline \multicolumn{7}{|l|}{ Age $60+($ Omitted $)$} \\
\hline $\begin{array}{l}\text { State \& Week FE } \\
\text { Observations }\end{array}$ & $\begin{array}{c}\checkmark \\
16,580\end{array}$ & $\begin{array}{c}\checkmark \\
16,580\end{array}$ & $\begin{array}{c}\checkmark \\
16,580\end{array}$ & $\begin{array}{c}\checkmark \\
16,580\end{array}$ & $\begin{array}{c}\checkmark \\
16,580\end{array}$ & $\begin{array}{c}\checkmark \\
16,580\end{array}$ \\
\hline
\end{tabular}

Notes: ${ }^{*} p<0.1,{ }^{* *} \mathrm{p}<0.05,{ }^{*} *{ }_{\mathrm{p}}<0.01$. Robust standard errors are clustered at the Statistical Area-by-Week level. Sampling weights are used since the unweighted estimates may be biased in the presence of endogenous sampling.

Abbreviation: FE, fixed effects. 
decreases by $22.40 \%, 15.43 \%$, and $26.96 \%$ compared to the control means of fever/chills (22.5\%), cough (12.7\%), and shortness of breath $(11.5 \%)$, respectively. As shown in Columns 4 to 6 , the Public Mask Mandate also reduces the incidences of fatigue, muscle/body aches, and headache by 7.70, 7.12, and 4.30 percentage points, respectively. These estimates correspond to the decreases by $63.63 \%, 59.33 \%$, and $33.86 \%$ compared to the control means of fatigue (12.1\%), muscle/body aches (12.0\%), and headache (12.7\%), respectively.

In addition, as shown in Columns 1, 4, and 5 of Table 4, living in states where the Public Mask Mandate is implemented further decreases the incidences of loss of appetite, nausea/vomiting, and diarrhea by $6.13,4.73$, and 2.84 percentage points, respectively. These estimates imply the average declines by $55.22 \%, 39.09 \%$, and $24.70 \%$ in the incidences of loss of appetite, nausea/vomiting, and diarrhea compared to the fraction of mandate unexposed individuals reporting such symptoms (ie $11.1 \%, 12.1 \%$, and $11.5 \%$ respectively).

\section{Discussion}

Collectively, we find strong economic and statistical evidence that mandating masks in public significantly lowers the incidence of developing COVID-19 symptoms at the individual level. Specifically, the number of COVID-19 symptoms declines by 0.43 for those residing in states where people are required to wear masks in public. The mandate also decreases the likelihood of exhibiting any symptoms within the last seven days by

Table 4 The Impact of Public Mask Mandate by Symptom (Continued)

\begin{tabular}{|c|c|c|c|c|c|}
\hline & $\begin{array}{l}\text { Loss of Appetite } \\
\text { (I) }\end{array}$ & $\begin{array}{c}\text { Sore Throat } \\
\text { (2) }\end{array}$ & $\begin{array}{c}\text { Congestion or Runny Nose } \\
\text { (3) }\end{array}$ & $\begin{array}{c}\text { Nausea or Vomiting } \\
\text { (4) }\end{array}$ & $\begin{array}{c}\text { Diarrhea } \\
\text { (5) }\end{array}$ \\
\hline Public Mask Mandate & $\begin{array}{l}-0.0613^{* * * *} \\
(0.0168)\end{array}$ & $\begin{array}{l}-0.0024 \\
(0.025 \mathrm{I})\end{array}$ & $\begin{array}{l}-0.0093 \\
(0.0225)\end{array}$ & $\begin{array}{l}-0.0473^{* * *} \\
(0.0167)\end{array}$ & $\begin{array}{c}-0.0284^{* * * *} \\
(0.0096)\end{array}$ \\
\hline Being Male & $\begin{array}{l}-0.018 I^{* *} \\
(0.0084)\end{array}$ & $\begin{array}{l}-0.0240 * * \\
(0.0101)\end{array}$ & $\begin{array}{l}-0.0287^{* * * *} \\
(0.0100)\end{array}$ & $\begin{array}{l}-0.0250 * * * \\
(0.0070)\end{array}$ & $\begin{array}{l}-0.0075 \\
(0.0080)\end{array}$ \\
\hline Having Bachelor's Degree & $\begin{array}{l}-0.0079 \\
(0.0096)\end{array}$ & $\begin{array}{l}-0.0086 \\
(0.0059)\end{array}$ & $\begin{array}{c}-0.0183^{*} \\
(0.0095)\end{array}$ & $\begin{array}{l}-0.0070 \\
(0.0087)\end{array}$ & $\begin{array}{l}-0.0066 \\
(0.0058)\end{array}$ \\
\hline Being Non-white & $\begin{array}{c}0.0410 \\
(0.0257)\end{array}$ & $\begin{array}{l}-0.0128 \\
(0.0178)\end{array}$ & $\begin{array}{l}-0.0419 \\
(0.0288)\end{array}$ & $\begin{array}{c}0.0230 \\
(0.0230)\end{array}$ & $\begin{array}{l}-0.0149 \\
(0.0190)\end{array}$ \\
\hline Living in Urban Areas & $\begin{array}{l}-0.0065 \\
(0.0129)\end{array}$ & $\begin{array}{c}0.0085 \\
(0.0143)\end{array}$ & $\begin{array}{l}-0.0107 \\
(0.0151)\end{array}$ & $\begin{array}{c}0.0037 \\
(0.0130)\end{array}$ & $\begin{array}{c}0.0019 \\
(0.0125)\end{array}$ \\
\hline Household Size & $\begin{array}{c}0.0033 \\
(0.0045)\end{array}$ & $\begin{array}{c}0.0021 \\
(0.0046)\end{array}$ & $\begin{array}{c}0.0056 \\
(0.0055)\end{array}$ & $\begin{array}{c}0.0063 \\
(0.0047)\end{array}$ & $\begin{array}{c}0.0014 \\
(0.0052)\end{array}$ \\
\hline Share of Children $(<18)$ & $\begin{array}{l}-0.0240 \\
(0.0392)\end{array}$ & $\begin{array}{l}-0.0161 \\
(0.0332)\end{array}$ & $\begin{array}{l}-0.0275 \\
(0.0508)\end{array}$ & $\begin{array}{l}-0.0640^{* *} \\
(0.0319)\end{array}$ & $\begin{array}{c}0.0342 \\
(0.0432)\end{array}$ \\
\hline Age 18-29 & $\begin{array}{c}0.0406 * * * \\
(0.0146)\end{array}$ & $\begin{array}{c}0.0419 * * * \\
(0.0137)\end{array}$ & $\begin{array}{l}0.0499 * \\
(0.0302)\end{array}$ & $\begin{array}{l}0.0358 * * \\
(0.0153)\end{array}$ & $\begin{array}{c}0.0243 \\
(0.0171)\end{array}$ \\
\hline Age $30-34$ & $\begin{array}{l}0.042 I^{* * *} \\
(0.0131)\end{array}$ & $\begin{array}{l}0.0393 * * * \\
(0.0119)\end{array}$ & $\begin{array}{l}0.0250 \\
(0.0183)\end{array}$ & $\begin{array}{c}0.0398^{* * *} \\
(0.0097)\end{array}$ & $\begin{array}{c}0.0316 * * * \\
(0.0106)\end{array}$ \\
\hline Age $45-59$ & $\begin{array}{c}0.0315^{* * *} \\
(0.0077)\end{array}$ & $\begin{array}{c}0.0117 \\
(0.0093)\end{array}$ & $\begin{array}{l}-0.0048 \\
(0.0238)\end{array}$ & $\begin{array}{c}0.0319 * * * \\
(0.0101)\end{array}$ & $\begin{array}{c}0.0042 \\
(0.0121)\end{array}$ \\
\hline \multicolumn{6}{|l|}{ Age 60+ (Omitted) } \\
\hline $\begin{array}{l}\text { State \& Week FE } \\
\text { Observations }\end{array}$ & $\begin{array}{c}\checkmark \\
16,580\end{array}$ & $\begin{array}{c}\checkmark \\
16,580\end{array}$ & $\begin{array}{c}\checkmark \\
16,580\end{array}$ & $\begin{array}{c}\checkmark \\
16,580\end{array}$ & $\begin{array}{c}\checkmark \\
16,580\end{array}$ \\
\hline
\end{tabular}

Notes: ${ }^{*} p<0.1, *_{p}^{*}<0.05$, *** $p<0.01$. Robust standard errors are clustered at the Statistical Area-by-Week level. Sampling weights are used since the unweighted estimates may be biased in the presence of endogenous sampling.

Abbreviation: FE, fixed effects. 
10.52 percentage points. Individuals are 0.29 percentage points less likely to develop all 11 symptoms if the Public Mask Mandate is effective in the residential state. Regarding individual symptoms, individuals residing in states where the Public Mask Mandate is in place are $4.83,1.96,3.10$, and 7.70 percentage points less likely to suffer from fever/chills, cough, shortness of breath, and fatigue, respectively. The Public Mask Mandate also reduces the incidences of muscle/body aches, headache, loss of appetite, nausea/vomiting, and diarrhea by $7.12,4.30,6.13,4.73$, and 2.84 percentage points respectively.

The results of our study also reveal the relationship between overall COVID-19 related symptoms and individual characteristics. Generally, males tend to have fewer symptoms relative to females. Individuals with bachelor's degrees seem to display fewer symptoms relative to those without bachelor's degrees. Perhaps, the more educated are more capable of protecting themselves. Besides, we also find that those living in larger size households are more susceptible than those from smaller size households. This is not surprising that a large number of people living in the same place poses higher risks of COVID-19 symptoms. Furthermore, our findings indicate that the young are more likely to exhibit COVID-19 symptoms compared to the elderly. It could be the case that young people have to go outside more frequently than the elderly, thus being exposed to higher risks. Finally, individuals with more children seem to have fewer COVID-19 symptoms. It could be because these individuals might be more careful in COVID-19 prevention practice to protect their children.

Our findings are consistent with prior studies on the impacts of state-level non-pharmaceutical policies on public health and COVID-19 prevention. In particular, it is documented that lockdowns or shelter-in-place orders, which require people to stay at home and businesses to shut down, can decrease COVID-19 infection, hospitalization, and deaths. ${ }^{7,17,18}$ Besides, state eviction moratorium that temporarily halts evictions and allows extension on rent payments for financially distressed tenants due to COVID-19 has been shown to reduce COVID-19 infection and mortality rate. ${ }^{19}$ Closer to our paper, several studies have reported the effectiveness of mask-wearing in downsizing COVID-19 infection growth rate and mortality. ${ }^{20-22}$

Since the virus is transmitted from human to human via respiratory droplets, there are multiple reasons why wearing a mask can protect individuals from the risk of infection. First, it is documented that pathogen-bearing droplets can travel from 23 to 27 feet, much farther than the 6-feet distance recommended for social distancing. ${ }^{23}$ Furthermore, a study by Leung et al shows that the exhaled breath of virus patients can have viral RNA and it is also possible for healthy people to accidentally inhale pathogens containing droplets. ${ }^{9}$ Therefore, masking or face-covering can lower the risk of catching these droplets not only from infected people but also from those with asymptomatic diseases.

The findings presented in this study underlines the value of mandating face masks among the general public in preventing COVID-19 infection during the early stage. Despite the availability of COVID-19 vaccines, there is still a probability of the fully vaccinated getting infected with the virus. ${ }^{11}$ Therefore, mask use is still relevant for the ongoing pandemic, and individuals are still encouraged to wear face masks in public. ${ }^{24}$ Besides, even though vaccines are available at the current stage, the vaccination rate can be precarious, which means that loosening pandemic-related restrictions such as masking or facecovering in public places should be conducted very carefully. For example, countries such as Germany and Spain had to strengthen their mask requirements when faced with a slowdown in vaccination rates and a surge in COVID-19 cases. ${ }^{25}$ In many developing countries where access to vaccines is still limited, mask use should still be one of the effective non-pharmaceutical measures to downsize community transmission and lessen the burden of the pandemic. For future outbreaks, mask use might still be an appropriate policy response given its effectiveness in decreasing infection.

Regarded as a profoundly important pillar of pandemic control, public mask-wearing is among the most effective policies at reducing the spread of the virus when compliance is high. ${ }^{12}$ Therefore, governments need to communicate with the public on the benefits of face masks to ensure the highest compliance. It is also important for political leaders and doctors to serve as role models for the public. $^{13}$ Nevertheless, the shortage of medical resources including masks at the onset of the pandemic could have affected the process of policy implementation. ${ }^{26}$ Therefore, when there is a shortage of face masks, the use of homemade masks should be encouraged since the efficacy of homemade masks, despite being lower than medical masks, is superior to no protection at all. ${ }^{10}$ Furthermore, some degree of interventions in the mask market such as a subsidy is justified given the positive externalities it can generate. In addition, the 
mask use policy might be implemented in conjunction with other strategies such as social distancing to maximize potential benefits, especially in situations where the vaccination rate is low.

This study has several limitations. First, other policies at the beginning of the pandemic such as lockdowns and eviction moratorium are not accounted for in the model. Future work may consider examining how the combination of such policies affects public health. Second, our paper evaluates the impacts of the Public Mask Mandate that requires the use of face masks by the general public in public space. It is possible that mask use had been required for a subset of the population (eg frontline essential workers) before the mandate became effective. Our study cannot account for this possibility. Finally, we examine how the Public Mask Mandate affects the individual's likelihood of developing COVID-19 symptoms, not the individual's likelihood of getting infected with COVID-19. Despite exhibiting the symptoms has been well established to be strong predictors of COVID-19 infection, the relationship between the Public Mask Mandate and individual probability of having COVID-19 are still indirect, thus only providing suggestive evidence for the relationship of interest. Future work may consider shedding more concrete evidence on this relationship.

\section{Conclusion}

We evaluate whether mandating the use of masks in public can protect people from developing COVID-19 symptoms during the early stage of the pandemic. Our study utilizes the COVID Impact Survey that focuses exclusively on individual experiences during the COVID-19 outbreak in the US Our identification strategy exploits the differential timing of the Public Mask Mandate implementation across the US within a difference-in-differences framework. Our main result suggests that the Public Mask Mandate lowers the incidence of developing all COVID-19 symptoms by 0.29 percentage points. Taking the proportion of individuals who are not subject to the mandate and display all symptoms as the benchmark, our estimate implies the average decrease by $290 \%$.

The result provides suggestive evidence for the enormous benefits of wearing masks in public for individual health during the early stage of the pandemic. Given its effectiveness in inhibiting COVID-19 symptoms, mask use is still relevant in the ongoing pandemic. It could serve as a protective barrier for unvaccinated individuals and could still be an important non-pharmaceutical tool to curtail virus transmission in countries where access to vaccines is limited. Given its effectiveness in decreasing infection, public mask-wearing might still be an appropriate policy response to future outbreaks.

\section{Acknowledgments}

The study was supported by The Youth Incubator for Science and Technology Programe, managed by Youth Development Science and Technology Center - Ho Chi Minh Communist Youth Union and Department of Science and Technology of Ho Chi Minh City, the contract number is “ $10 / 2020 / \mathrm{HĐ-KHCNT-VU”} \mathrm{ngày} 30$ tháng 12 năm 2020”.

\section{Disclosure}

The author reports no conflicts of interest in this work.

\section{References}

1. Alon TM, Doepke M, Olmstead-Rumsey J, Tertilt M. The impact of COVID-19 on gender equality. Working Paper No. w26947. National Bureau of Economic Research; 2020.

2. Chetty R, Friedman JN, Hendren N, Stepner M. How did Covid-19 and stabilization policies affect spending and employment? A new real-time economic tracker based on private sector data. Working Paper No. w27431. National Bureau of Economic Research; 2020.

3. Le K, Nguyen M. The psychological burden of the COVID-19 pandemic severity. Econ Hum Biol. 2021a;41:100979. doi:10.1016/j. ehb.2021.100979

4. Le K, Nguyen M. The psychological consequences of COVID-19 lockdowns. Int Rev Appl Econ. 2021b;35(2):147-163. doi:10.1080/ 02692171.2020 .1853077

5. Jarvis CI, Van Zandvoort K, Gimma A, et al. Quantifying the impact of physical distance measures on the transmission of COVID-19 in the UK. BMC Med. 2020;18(1):1-10. doi:10.1186/s12916-02001597-8

6. Ferguson NM, Laydon D, Nedjati-Gilani G, et al. Impact of nonpharmaceutical interventions (NPIs) to reduce COVID-19 mortality and healthcare demand. Imperial College London. doi:10.25561/ 77482

7. Hellewell J, Abbott S, Gimma A, et al. Feasibility of controlling COVID-19 outbreaks by isolation of cases and contacts. Lancet Glob Health. 2020;8(4):e488-e496. doi:10.1016/S2214-109X(20)30074-7

8. Zhang X, Warner ME. COVID-19 policy differences across US states: shutdowns, reopening, and mask mandates. Int J Environ Res Public Health. 2020;17(24):9520. doi:10.3390/ijerph17249520

9. Leung NH, Chu DK, Shiu EY, et al. Respiratory virus shedding in exhaled breath and efficacy of face masks. Nat Med. 2020;26 (5):676-680. doi:10.1038/s41591-020-0843-2

10. Davies A, Thompson KA, Giri K, Kafatos G, Walker J, Bennett A. Testing the efficacy of homemade masks: would they protect in an influenza pandemic? Disaster Med Public Health Prep. 2013;7 (4):413-418. doi:10.1017/dmp.2013.43

11. Boyarsky BJ, Werbel WA, Avery RK, et al. Antibody response to 2-dose SARS-CoV-2 mRNA vaccine series in solid organ transplant recipients. JAMA. 2021;325(21):2204-2206. doi:10.1001/ jama.2021.7489

12. Howard J, Huang A, Li Z, et al. An evidence review of face masks against COVID-19. Proc Natl Acad Sci. 2021;118(4):e2014564118. doi:10.1073/pnas.2014564118 
13. Lim S, Yoon HI, Song KH, Kim ES, Kim HB. Face masks and containment of COVID-19: experience from South Korea. J Hosp Infect. 2020;106(1):206. doi:10.1016/j.jhin.2020.06.017

14. Alimohamadi Y, Sepandi M, Taghdir M, Hosamirudsari H. Determine the most common clinical symptoms in COVID-19 patients: a systematic review and meta-analysis. J Prev Med Hyg. 2020;61(3):E304.

15. Grant MC, Geoghegan L, Arbyn M, et al. The prevalence of symptoms in 24,410 adults infected by the novel coronavirus (SARS-CoV2; COVID-19): a systematic review and meta-analysis of 148 studies from 9 countries. PLoS One. 2020;15(6):e0234765. doi:10.1371/journal.pone. 0234765

16. Assaker R, Colas AE, Julien-Marsollier F, et al. Presenting symptoms of COVID-19 in children: a meta-analysis of published studies. $\mathrm{Br}$ $J$ Anaesth. 2020;125(3):e330-e332. doi:10.1016/j.bja.2020.05.026

17. Lyu W, Wehby GL. Shelter-in-place orders reduced COVID-19 Mortality and reduced the rate of growth in hospitalizations: study examine effects of shelter-in-places orders on daily growth rates of COVID-19 deaths and hospitalizations using event study models. Health Aff. 2020a;39(9):1615-1623. doi:10.1377/hlthaff.2020.00719

18. Roux J, Massonnaud C, Crépey P. COVID-19: one-month impact of the French lockdown on the epidemic burden. MedRxiv. 2020. doi:10.1101/2020.04.22.20075705

19. Jowers K, Timmins C, Bhavsar N, Hu Q, Marshall J. Housing precarity \& the COVID-19 pandemic: impacts of utility disconnection and eviction moratoria on infections and deaths across US Counties. NBER Working paper No. w28394. National Bureau of Economic Research; 2021.
20. Eikenberry SE, Mancuso M, Iboi E, et al. To mask or not to mask: modeling the potential for face mask use by the general public to curtail the COVID-19 pandemic. Infect Dis Model. 2020;5:293-308. doi:10.1016/j.idm.2020.04.001

21. Kheirallah KA, Alsinglawi B, Alzoubi A, et al. The effect of strict state measures on the epidemiologic curve of COVID-19 infection in the context of a developing country: a simulation from Jordan. Int J Environ Res Public Health. 2020;17(18):6530. doi:10.3390/ijerph17186530

22. Lyu W, Wehby GL. Community use of face masks and COVID-19: evidence from a natural experiment of state mandates in the US: study examines impact on COVID-19 growth rates associated with state government mandates requiring face mask use in public. Health Aff. 2020b;39(8):1419-1425. doi:10.1377/hlthaff.2020.00818

23. Bourouiba L. Turbulent gas clouds and respiratory pathogen emissions: potential implications for reducing transmission of COVID-19. JAMA. 2020;323(18):1837-1838.

24. Centers for Disease Control and Prevention. Choosing safer activities; 2021. Available from: https://www.cdc.gov/coronavirus/ 2019-ncov/daily-life-coping/participate-in-activities.html. Accessed August 9, 2021.

25. Peeples L. What the science says about lifting mask mandates. Nature. 2021;593(7860):495-498. doi:10.1038/d41586-021-01394-0

26. Xi C, Chang Y, Xian P, et al. Management of personal protective equipment shortage and other medical resources during the COVID-19 pandemic. Transl Perioper Pain Med. 2021;8 (3):365-371.
ClinicoEconomics and Outcomes Research

\section{Publish your work in this journal}

ClinicoEconomics and Outcomes Research is an international, peerreviewed open-access journal focusing on Health Technology Assessment, Pharmacoeconomics and Outcomes Research in the areas of diagnosis, medical devices, and clinical, surgical and pharmacological intervention. The economic impact of health policy and health systems

\section{Dovepress}

organization also constitute important areas of coverage. The manuscript management system is completely online and includes a very quick and fair peer-review system, which is all easy to use. Visit http://www.dovepress.com/testimonials.php to read real quotes from published authors. 